\title{
SPECIFIC CHARACTERISTICS OF THE FUNCTIONAL STATE OF THE MYOCARDIUM IN PATIENTS WITH STABLE ANGINA PECTORIS COMBINED WITH THE METABOLIC SYNDROME
}

\section{I.V. Malyshevs'ka}

Abstract. The paper presents the results of an analysis of the influence of the presence of the metabolic syndrome (MS) on the myocardial dysfunction. More marked signs of a remodelling of the left ventricle (LV) have been established in patients with a combination of stable angina (SA) and MS, irrespective of the state of the global contractility of the LV. We haven't detected a correlation between the indices of the intracardiac hemodynamics and the markers of the atherosclerotic process, namely, the level of total cholesterol (TCS) and C-reactive protein (CRP).

Key words: stable angina pectoris, metabolic syndrome, echocardiography.

Bukovinian State Medical University (Chernivtsi)

Рецензент - проф. О.С. Полянська
Buk. Med. Herald. - 2013. - Vol. 17, № 2 (66). - P. 83-86

Надійшла до редакції 16.05.2013 року

(C) І.В. Малишевська, 2013

УДК 616.72-007.24:[612.398:577.12+612.017

О.П. Микитюк

\section{ДОБОВА ТА СЕЗОННА ХАРАКТЕРИСТИКА ПРОЦЕСІВ ВІЛЬНОРАДИКАЛЬНОЇ МОДИФІКАЦІЇ МАКРОМОЛЕКУЛ ТА АНТИОКСИДАНТНОГО ЗАХИСТУ У ХВОРИХ НА ОСТЕОАРТРОЗ}

Буковинський державний медичний університет, м. Чернівці

Резюме. Проведено порівняння добової та сезонної організації вмісту в крові продуктів вільнорадикальної модифікації макромолекул та активності факторів антиоксидантного захисту в крові хворих на остеоартроз. Показано, що остеоартроз супроводжується пору-

Вступ. Більшість функцій організму характеризується циклічністю вродовж певних часових проміжків та узгодженістю цих коливань [1]. Найбільшу увагу приділяють вивченню добових та сезонних ритмів, оскільки вони регулюються чітко описаними факторами. Часова дезорганізація (десинхроноз) біологічних функцій $є$ ключем фізіологічного процесу старіння і патогенезу захворювань, оскільки полягає в порушенні зворотного зв'язку регуляції. Вона трапляється при перебуванні організму в екстремальних для нього умовах, за впливу патогенних чинників, та іноді - у перехідні фази річного циклу (весна та осінь) [2].

Ритмічність етіологічних факторів і часова організація органів-мішеней зумовлює варіабельність суб' єктивних та об'єктивних клінічних проявів захворювань. Існування добових варіацій клінічно-лабораторних параметрів у хворих на остеоартроз (ОА) - патологію опорно-рухового апарату, підтверджене неодноразово. Проте при плануванні більшості досліджень та діагностичних процедур добова динаміка біохімічних показників враховується не завжди.

Мета дослідження. Аналіз добової динаміки та міжсезонних відмінностей вмісту в крові продуктів вільнорадикальної модифікації макромо- шенням як добової, так і сезонної організації вмісту в організмі досліджуваних показників.

Ключові слова: остеоартроз, добові ритми, сезонні ритми, вільнорадикальні процеси, антиоксиданти. захисту у хворих на остеоартроз.

Матеріал і методи. Для вирішення задач дослідження обстежено 88 хворих на ОА, що перебували на стаціонарному лікуванні в ревматологічному відділенні міської лікарні № 3 м.Чернівці. Співвідношення „жінки:чоловіки”

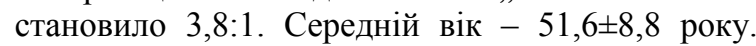
Тривалість захворювання склала $8,4 \pm 4,6$ року. Діагноз ОА встановлювали на основі уніфікованих критеріїв, розроблених Американською Ревматологічною Асоціацією.

У всіх пацієнтів отримано згоду на участь у дослідженні відповідно до вимог Належної Клінічної Практики. Всі процедури відповідали стандартам Гельсінської декларації 1975 р. та їі перегляду 1983 р.

Для характеристики добових та сезонних особливостей клінічної картини у хворих на ОА проводили посезонний розподіл обстежених пацієнтів (обстежено 20 пацієнтів - узимку, 28 навесні, 20 - влітку та 20 - в осінні місяці). Контрольні обстеження виконані в групі практично здорових осіб $(\mathrm{n}=42)$, у яких на час обстеження не було загострень хронічної патології органів дихання чи травного каналу, серцево-судинної системи, а та- 


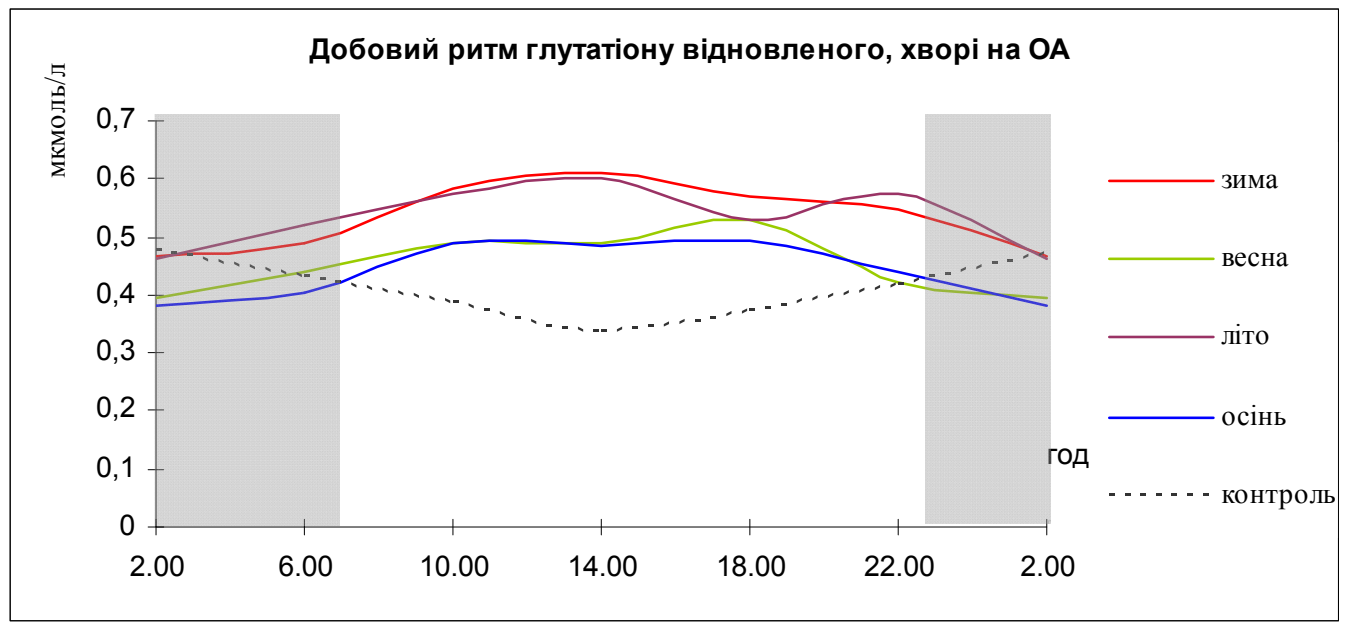

Рис. 1. Добова та сезонна організація вмісту відновленого глутатіону в крові хворих на остеоартроз до лікування

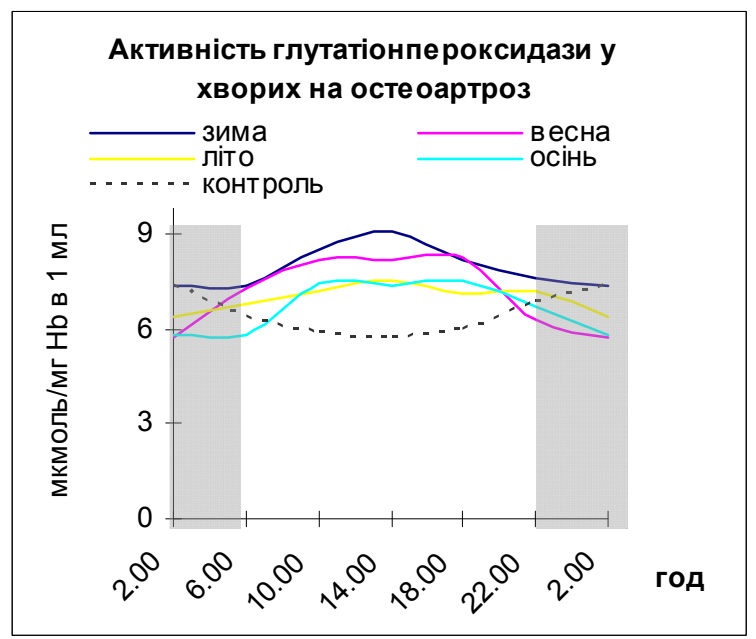

A

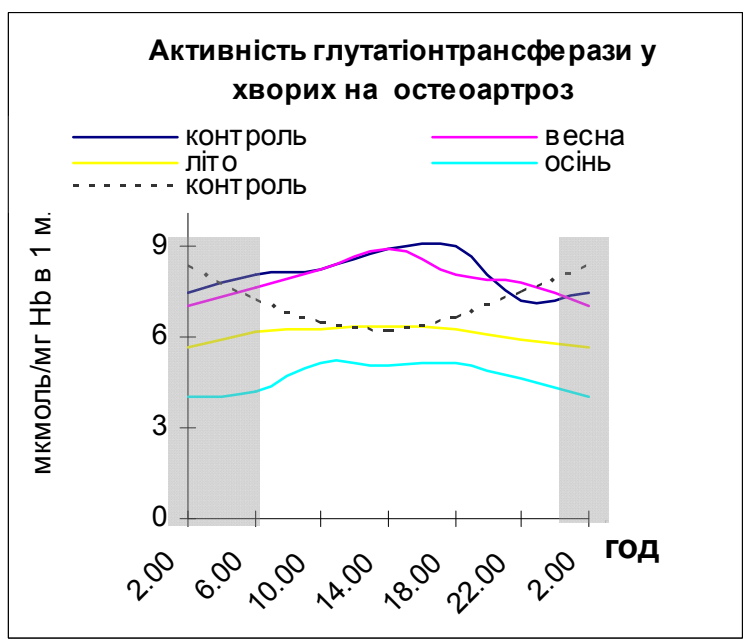

Б

Рис. 2. Добова та сезонна організація активності глутатіонпероксидази (А) та глутатіонтрансферази (Б) - у крові хворих на остеоартроз

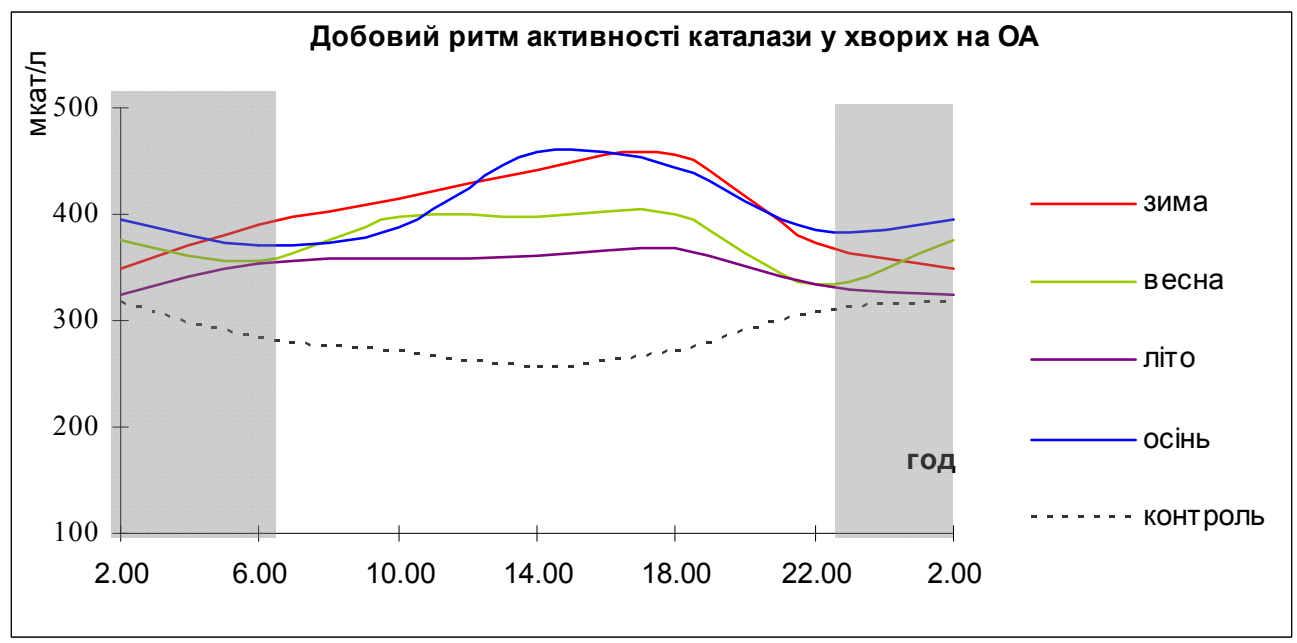

Рис. 3. Добова та сезонна організація активності каталази в крові хворих на остеоартроз

кож не було гострих захворювань, включаючи респіраторні, за останні три місяці. Особи, що увійшли до групи контролю, були зіставними 3 пацієнтами інших груп за віком та статтю.
Проведено обстеження хворих на ОА при надходженні до стаціонару: вивчення інтенсивності вільнорадикального окиснення ліпідів (ВОЛ), вільнорадикальної модифікації білків (ВМБ); 


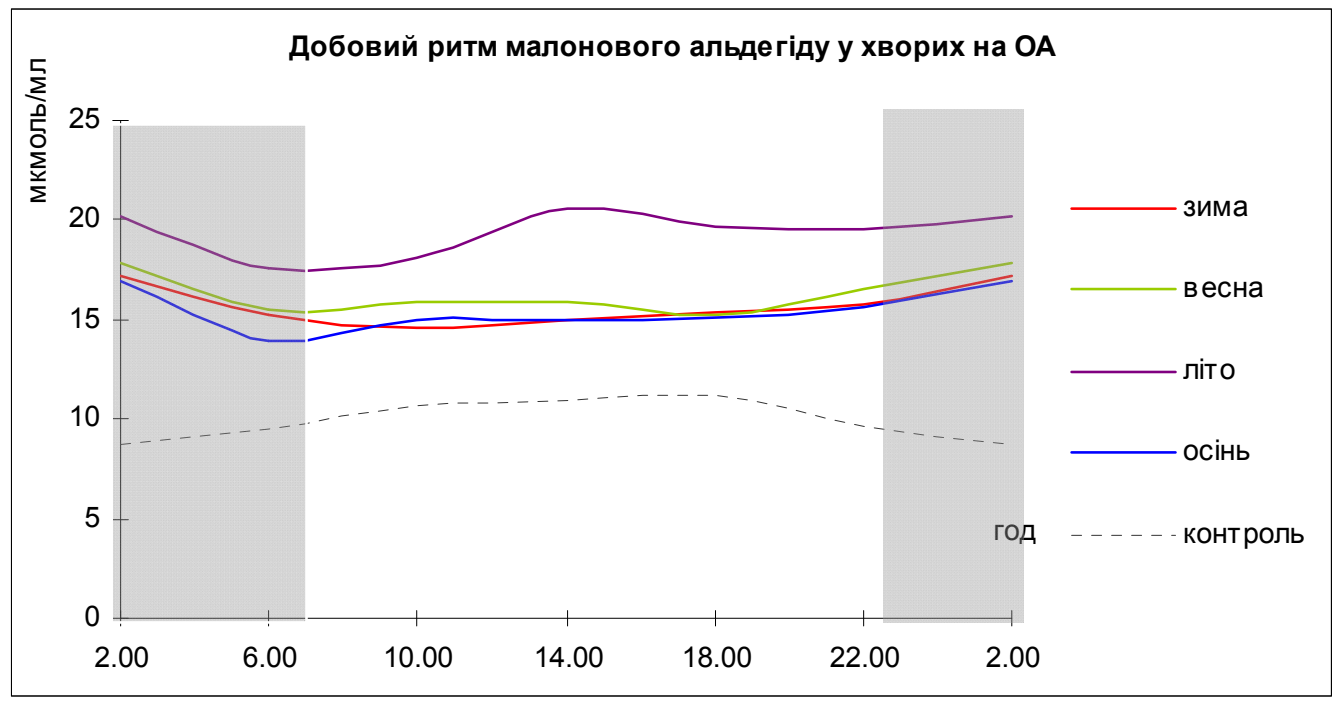

Рис. 4. Добова та сезонна організація вмісту малонового альдегіду крові хворих на остеоартроз

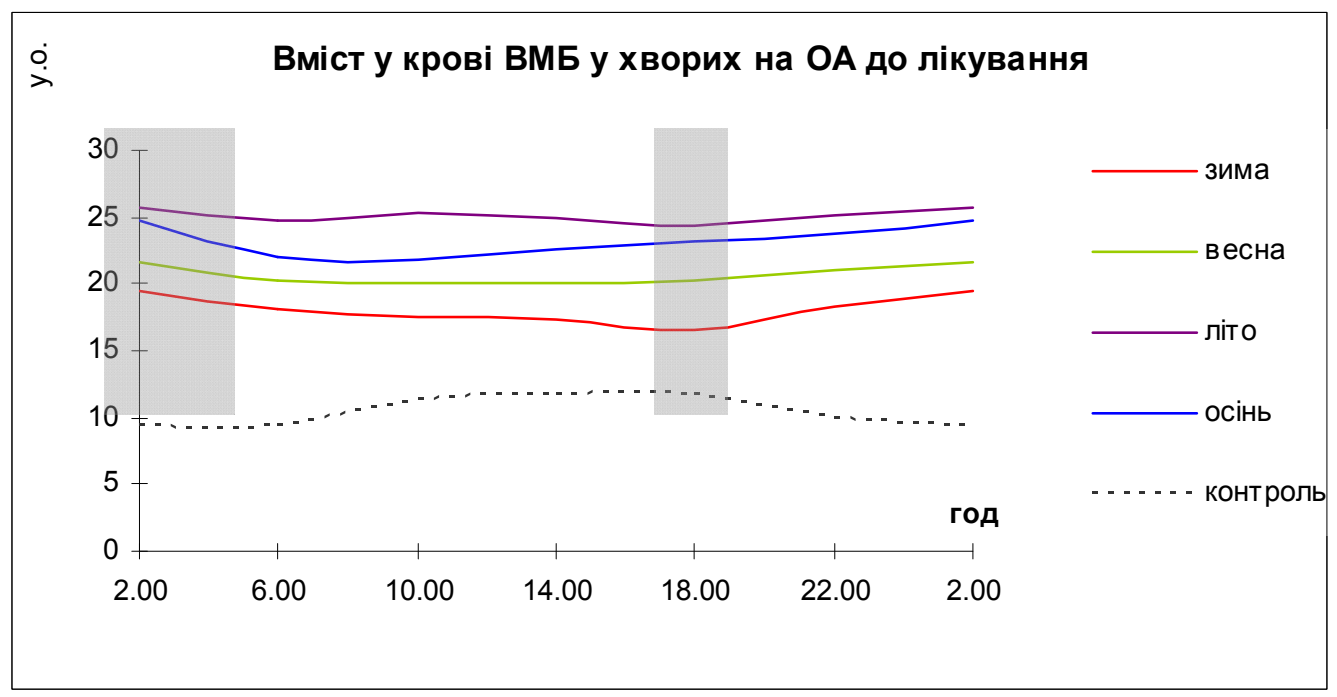

Рис. 5. Добова та сезонна організація вмісту продуктів вільнорадикальної модифікації білків у крові хворих на остеоартроз

стану антиоксидантного захисту (АОЗ) - за вмістом відновленого глутатіону (ВГ), активностями каталази, глутатіонпероксидази (ГП), глутатіонтрансферази (ГТ). Визначення проведені впродовж 24 годин із 6-годинним інтервалом. Всі хворі були синхронізованими за часом прийому їжі та режимом активності/відпочинку (нічний сон з 23.00 до 7.00).

Математична обробка отриманих даних проводилася з використанням варіаційного статистичного аналізу на IBM PC Pentium III. Достовірність змін варіацій у разі нормального розподілу у вибірках визначали за парним критерієм Стьюдента, в інших випадках - за непараметричним парним tкритерієм Уілкоксона. Результати вважали достовірними, коли коефіцієнт достовірності складав 0,05 або менше. Оцінку характеру ритмів показників проводили з використанням індивідуального та групового Косинор-аналізу, на базі програми Chronos-Fit (Гейдельберг, Німеччина, 2002 р.).

Результати дослідження та їх обговорення. У пацієнтів з ОА до лікування узагальнений ритм
ВГ втрачав добову залежність порівняно 3 контролем. Середньодобовий вміст ВГ зростав на $19,5 \%(\mathrm{p}<0,05)$. Хронограми хворих на ОА та здорових осіб набували інверсного характеру (рис. 1). Положення максимуму ВГ у хворих на ОА припадало на денний (10.00-14.00) період.

Аналіз міжсезонних відмінностей показав тенденцію до зменшення вмісту ВГ у крові хворих на ОА у весняний та осінній періоди та виявив більші концентрації антиоксиданта зимою і влітку.

Добові профілі глутатіонових ферментів ГП та ГТ - у хворих на ОА зазнавали таких же змін, як і вміст у крові ВГ (втрата циркадіанної ритмічності, шифт максимуму на денні години). Сезонна динаміка, проте, була дещо іншою - максимальна активність ферментів виявлена взимку та навесні, мінімальна - восени (рис. 2).

У хворих на ОА активність каталази теж не виявляла циркадіанної періодичності. Влітку та зимою виявлено значне іiі підвищення в крові пацієнтів у денний час - на $33,4 \%(p<0,05)$ i 
37,6 \% ( $<0,05)$ відповідно, без змін концентрації у нічні години. Весною та восени активність у денні години зростала недостовірно, а в нічні зменшувалася порівняно 3 контролем на $15,6 \%$ та 18,2 \% відповідно. Все це надавало 24годинним профілям пацієнтів інверсного вигляду (максимальні значення - у період 10.00-18.00) порівняно 3 контролем (рис.3). Середньодобові значення у різні пори року між собою не відрізнялися, і були вищими за контрольні на 24-29 \% $(\mathrm{p}<0,05)$.

Аналіз ритмічної організації рівня МА крові за ОА (рис. 4) дозволив виявити втрату добового характеру, встановленого в групі контролю, та вірогідне зростання середньодобової концентрації за рахунок збільшення вмісту у всіх часових проміжках проти рівня здорових осіб. Максимальні рівні МА у групі хворих на ОА виявляли у вечірній час (зі збільшенням концентрації вдвічі порівняно 3 групою контролю $(\mathrm{p}<0,05))$, вдень показник достовірно збільшувався в 1,5 раза $(\mathrm{p}<0,05)$. Добова концентрація МА була інверсною щодо вмісту ВГ, активності антиоксидантних ферментів.

Міжсезонних достовірних відмінностей при порівнянні відповідних профілів, отриманих при дослідженні хворих у різні місяці, не виявляли, хоча спостерігали тенденцію до зростання вмісту МА влітку (на 15-18 \% в усі часові проміжки).

Оцінка вмісту продуктів ВМБ виявила, що останні за ОА змінювалися в крові із закономірностями, описаними для МА. Спостерігалася інверсія ритму порівняно із контрольною хронограмою (зростання показника в 2,3 раза ввечері $(\mathrm{p}<0,05)$ та в 1,8 раза - вдень $(\mathrm{p}<0,05))$ - та зсув максимуму на денний час, втрата циркадіанного характеру, збільшення середньодобового рівня у 2,0-2,3 раза залежно від пори року за рахунок достовірного зростання значень показника в усі досліджувані проміжки (рис.5). Аналіз відмінностей хронограм, що характеризують ВМБ у різні пори року, виявив достовірне збільшення вмісту іiі продуктів у крові хворих на ОА влітку порівняно із зимою (на $28,1 \%(\mathrm{p}<0,05))$.

У відповідь на коливання рівня кисню у хрящі за ОА хондроцити продукують аномальні рівні РФК. Основними є супероксиданіон та NO, що зумовлюють появу підвищеної кількості пероксинітриту, $\mathrm{H}_{2} \mathrm{O}_{2}$ [3], а також мієлопероксидази і гіпохлористої кислоти. За наявності заліза та $\mathrm{H}_{2} \mathrm{O}_{2}$ хондроцити вивільняють гідроксил-радикали, які реагують 3 ненасиченими жирними кислотами мембран та ініціюють ланцюгову реакцію, продукуючи радикали із тривалим часом існування.

Відповідь клітин на РФК залежить від їх відновлювального потенціалу. Коли рівень ї продукції не перевищує нейтралізуючих можливостей, вони задіяні в контролі клітинних функцій. РФК безпосередньо регулюють фактори транскрипції, оксидативно модифікуючи цистеїнові залишки молекул (NF-kB, AP-1, Sp-1, C-
Myb, p53, egr-1, HIF-1 $\alpha$ ), задіяних у реалізації відповіді тумор-некротизуючого фактора й інтерлейкіну- $\beta$, активують МАРК систему, р38 каскади (останні відповідають за зміну фенотипу і синтетичного профілю хондроцитів). Оксидантний стрес спричиняє деградацію мембран, нуклеїнових кислот, екстрацелюлярного матриксу. ВМБ уможливлює появу внутрішньо- та міжмолекулярних ковалентних поперечних зв'язків [2], що стабілізує агрегати протеїнів і робить їх стійкішими до утилізації. МА зумовлює оксидацію волокон колагену, з порушенням їх біохімічних та біофізичних властивостей, робить їх схильними до деградації [6], реагує із залишками лізину і гістидину амінокислот, утворюючи стабільні похідні (альдегідне окиснення). Оксидантний стрес індукує й нестабільність теломер хондроцитів, постаріння останніх - все це може бути відповідальним за розвиток ОА [5].

Результати аналізу біоритмів параметрів, що віддзеркалюють розвиток процесів вільнорадикальної модифікації міжклітинної речовини у хворих на ОА, підтверджують сучасні погляди на те, що ці явища $є$ однією 3 важливих ланок пошкодження компонентів хряща [6]. У пацієнтів з ОА виявлено високі рівні кінцевих продуктів МА та ВМБ, що є одним із найважливіших механізмів реалізації пошкоджувальної дії РФК на структури клітин та компоненти матриксу.

Є повідомлення, що усереднений антиоксидантний статус пацієнтів з ОА суттєво менший за такий у здорових осіб. Вважають, що це наслідок надмірної утилізації антиоксидантів за наявності вільних радикалів, особливо за дії несприятливих факторів довкілля. Стверджують, що на початку розвитку запальної відповіді при захворюваннях зі схильністю до хронізації відбувається стійке зменшення ендогенної продукції МТ під впливом ТНФ- $\alpha$ (що може супроводжуватися наступним порушенням функціонування системи АО3), але дане порушення з часом минає [3]. Так, і в наших дослідженнях у обстежених пацієнтів абсолютний вміст ВГ, активності ГП та ГТ дещо зростали, хоча і не виконували ефективного скавенджування та знешкодження РФК ні в денний, ні, особливо, в нічний час.

\section{Висновок}

За остеоартрозу експресія реактогенних форм кисню в організмі в атиповий час (вночі), коли основні природні ресурси, спрямовані на компенсацію зазначених явищ у денний час, вичерпані, а нові, у силу патогенетичних особливостей захворювання (гіперцитокінемія, десинхроноз) не утворилися, зменшує шанси репарації на успіх, створює передумови для прогресування захворювання.

Перспективи подальших досліджень. Дослідження й облік хронобіологічних закономірностей створюють теоретичну базу для розробки методів ранньої діагностики, прогнозу та виділення факторів ризику розвитку патології. 


\section{Література}

1. Комаров Ф.И. Хронобиология и хрономедицина / Ф.И. Комаров, С.И. Рапопорт. - М.: Триада-Х, 2000. $488 \mathrm{c}$.

2. Inhibition of inducible nitric oxide synthase prevents lipid peroxidation in osteoarthritic chondrocytes / M. Bentz, C. Zaouter, Q. Shi [et al.] // J. Cell Biochem. - 2012. Vol. 113, №7. - P. 2256-2267.

3. Molecular mechanisms of cartilage remodelling in osteoarthritis. / J. Bertrand, C. Cromme, D. Umlauf [et al.] // Int. J. Biochem. Cell Biol. - 2010. - Vol. 42, № 10. P. 1594-1601.
4. Hardeland R. Circadian Rhythms, Oxidative Stress and Antioxidative Defense mechanisms / R. Hardeland, A. Coto-Montes, B. Poeggeler // Chronobiology International. - 2003. - Vol. 20, № 6. - P. 921-962.

5. Li D. Reactive oxygen species: the 2-edged sword of osteoarthritis / D. Li, G. Xie, W. Wang // Am. J. Am. J. Med. Sci. - 2012. - Vol. 344, № 6. - P. 486-490.

6. Molecular regulation of articular chondrocyte function and its significance in osteoarthritis / J.P. Schroeppel, J.D. Crist, H.C. Anderson [et al.] // Histol. Histopathol. 2011. - Vol. 26, № 3. - P. 377-394.

\title{
СУТОЧНАЯ И СЕЗОННАЯ ХАРАКТЕРИСТИКА ПРОЦЕССОВ СВОБОДНОРАДИКАЛЬНОЙ МОДИФИКАЦИИ МАКРОМОЛЕКУЛ И АНТИОКСИДАНТНОЙ ЗАЩИТЫ У БОЛЬНИХ С ОСТЕОАРТРОЗОМ
}

\section{о.П. Микитюк}

Резюме. Проведено сравнение суточной и сезонной организации содержания продуктов свободнорадикальной модификации макромолекул и активности факторов антиоксидантной защиты в крови больных с остеоартрозом. Показано, что остеоартроз сопровождается нарушением как суточной, так и сезонной организации содержания в организме больных исследуемых факторов. данты.

Ключевые слова: остеоартроз, суточные ритмы, сезонные ритмы, свободнорадикальные процессы, антиокси-

\section{DIURNAL AND SEASONAL CHARACTERISTIC OF FREE RADICAL MODIFICATION PROCESSES OF MACROMOLECULES AND ANTOXIDANT DEFENCE IN PATIENTS WITH OSTEOARTHRITIS}

\section{O.P. Mykytyuk}

Abstract. A comparison of the diurnal and seasonal organization of the blood content of free radical macromolecules modification products and the blood activity of the antioxidant defense factors of patients, suffering from osteoarthritis has been carried out. It has been demonstrated that the presence of osteoarthritis is accompanied with disturbances of both the diurnal and seasonal organisation of the content of the parameters under study in the organism.

Key words: osteoarthritis, diurnal rhythms, seasonal rhythms, free-radical processes, antioxidants.

Bukovinian State Medical University (Chernivtsi)

\section{ВИВЧЕННЯ ЕЛЕКТРОЛІТНОГО СКЛАДУ РОТОВОЇ РІДИНИ В ДІТЕЙ, ЯКІ ПРОЖИВАЮТЬ У МІСЦЕВОСТІ 3 НИЗЬКИМ ВМІСТОМ ЙОДУ ТА ФЛУОРУ В ОБ'ЄКТАХ ДОВКІЛЛЯ}

\author{
Івано-Франківський національний медичний університет \\ *Комунальна медична установа «Міська дитяча стоматологічна поліклініка», м. Чернівці
}

\begin{abstract}
Резюме. Дослідження проведені в 166 дітей трьох вікових груп (6, 9 та 12 років) із каріозним ураженням зубів різної інтенсивності, які з народження проживали в місцевості з недостатнім вмістом есенційних макро- та мікроелементів, зокрема Флуору та Йоду, в об'єктах довкілля. Контролем слугувала ротова рідина 46 здорових дітей відповідного віку, без патологічних змін твердих тканин зубів. Результати нашого дослідження засвідчили достовірне зменшення $(\mathrm{p}<0,05)$ концентрацій іонів кальцію та фосфат-іонів у ротовій рідині учнів у разі наявності каріозного ураження зубів порівняно зі здоровими дітьми відповідно на 20,87 \% та
\end{abstract}

13,13 \%. Найнижчі значення досліджуваних показників спостерігали в дітей всіх вікових груп із каріозним процесом зубів III ступеня активності. Зменшення рівня іонів кальцію та фосфат-іонів $є$ свідченням послаблення процесів мінералізації, що сприяє виникненню та прогресуванню каріозного ураження зубів. Вивчення електролітного складу ротової рідини в даного контингенту дітей може слугувати для визначення груп ризику, ранньої діагностики, своєчасного лікування та профілактики каріозного ураження зубів.

Ключові слова: діти, ротова рідина, електролітний склад. 